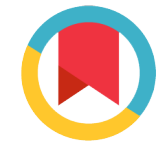

Check for updates

\section{Potential role of Factor V Leiden mutation in adverse pregnancy outcomes: An updated systematic review}

\author{
Nasibeh Roozbeh1, Farzaneh Banihashemi1, Mitra Mehraban², \\ Fatemeh Abdi3,*
}

*For correspondence:

abdi@sbmu.ac.ir

Competing interests: The authors declare that no competing interests exist.

Received: 18 October 2017 Accepted: 07 November 2017 Published: 18 December 2017

Copyright The Author(s) 2017. This article is published with open access by BioMedPress.

This article is distributed under the terms of the Creative Commons Attribution License (CC-BY 4.0) which permits any use, distribution, and reproduction in any medium, provided the original author(s) and the source are credited.

\section{Abstract}

Background: Thrombophilia is an inherited or acquired predisposition for development of thrombosis. One of the common thrombophilia polymorphisms is Factor $V$ Leiden ( $F V L$ ) mutation, which may contribute to negative pregnancy outcomes. This systematic review study seeks to describe the potential effects of factor $V$ Leiden mutation on adverse pregnancy outcomes. Methods: Pubmed, Embase, ISI Web of Sciences, Scopus, ScienceDirect, Proquest and Google Scholar, for articles published during 1996-2017. Articles were evaluated by the Strengthening the Reporting of Observational Studies in Epidemiology (STROBE) checklist for standard reporting. As well, the quality of studies was assessed by the Newcastle-Ottawa Scale (NOS). Results: A total of 14 studies were eligible based on the inclusion criteria. The papers were scored by the STROBE checklist. The range of STROBE score was $15-20$. Only $37.5 \%$ of the studies confirmed the relationship between fetal loss and FVL. The effect of FVL mutation on spontaneous abortions and In Vitro Fertilization (IVF) failures was demonstrated in all the studies. In the reviewed studies, there was no observed relationship between FVL mutation with intrauterine growth restriction (IUGR), preeclampsia, placental abruption or small for gestational age (SGA). 
Conclusion: The reviewed studies showed an unclear association between FVL mutation and stillbirth, IUGR, preeclampsia, or placental abruption. The exact effects of hereditary thrombophilia on pregnancy outcome is also still controversial. However, FVL mutation appeared to have an effect on spontaneous abortions and IVF failures. Therefore, screening patients for thrombophilic polymorphisms might be helpful.

\section{Keywords}

Factor V Leiden, Mutation, Pregnancy outcomes

\section{Introduction}

Factor $V$ Leiden (FVL) is a variant, mutated form of human factor $V$ (one of several substances that helps blood clot), which causes an increase in blood clotting. With this mutation, the secreted anticoagulant protein, which normally inhibits the pro-clotting activity of factor $V$, is not able to bind normally to factor V. This leads to a hypercoagulable state, i.e., an increased tendency for the patient to form abnormal and potentially harmful blood clots (De Stefano and Leone, 1995). FVL mutation is the most common known genetic factor that predisposes an individual to thrombosis (Dizon-Townson et al., 2005).

Thrombosis is a common cause of death in the U.S. Thrombophilia is an inherited or acquired predisposition to develop either venous or arterial thrombosis (Rodger, 2013). The combined prevalence of different types of thrombophilia in the general population exceeds one in ten. The most commonly reported type of acquired thrombophilia is the antiphospholipid syndrome (APS). The diagnostic criteria for this condition are presence of antiphospholipid antibodies, e.g. anticardiolipin antibodies ( $\mathrm{aCL}$ ), and/or lupus anticoagulant (LA) and anti- $\beta_{-}-2$-glycoprotein I ( $\left.a_{\beta} 2-G P I\right)$ antibodies, for two or more separate occasions and for at least 9-12 weeks apart (Simcox et al., 2015). Inherited risk factors of thrombophilia include protein C, protein S, and antithrombin (AT III) deficiency and FVL gene mutation (Carrington et al., 2005; Doyle and Monga, 2004). FVL gene mutation may cause miscarriage, preeclampsia, IUGR, placental abruption, and stillbirth in pregnant women (Gawish, 2011; Rai and Regan, 2006).

Thrombophilic disorders are in fact believed to exacerbate the state of hypercoagulability in pregnancy and lead to the formation of microthrombin and placental insufficiency (Kupferminc et al., 2011). Thrombophilia is a complex 
disorder with various risk factors. The most commonly reported form of acquired thrombophilia is the APS. FVL is the underlying cause of activated protein C resistance (APCR), and prothrombin time (PT) are considered to be two major genetic risk factors for the condition. Despite their significance, these two factors generally remain under-diagnosed due to the absence of symptoms and low risk of thrombosis in their carriers. Nevertheless, the presence of the mentioned factors may become clinically evident following exposure to other predisposing factors, including pregnancy, oral contraceptives, hormone replacement therapy (HRT) and vessel wall disorders, which encourage stasis and boost the risk of lifethreatening thrombotic events (Gawish, 2011).

Extensive research over the past 50 years has confirmed significant relationships between thrombophilia (both inherited and acquired) and elevated risk of serious obstetric complications such as miscarriage, stillbirth, severe preeclampsia, placental abruption, IUGR, and other adverse obstetric outcomes. Although the exact mechanisms involved are unknown, inadequate maternalfetal circulation and decreased placental perfusion caused by abnormal placental vasculature and disturbances in hemostasis might be responsible for the aforementioned complications (Pavlova et al., 2008) since higher frequency of FVL mutation has been documented in women with such complications (Kupferminc et al., 1999). Based on the results of previous studies, the rates of preterm births have increased over time. Furthermore, thrombophilia may have negative impacts on pregnancy outcomes, especially preterm birth and the consequent neonatal and childhood injuries and deaths, and can exert a heavy economic burden on society and families.

According to searches in various databases no systematic review has assessed the effect of FVL mutation on pregnancy outcomes in recent years. A systematic review article provides an outline of research study results and is the best method for summarizing the overall evidence (Abdi and Roozbeh, 2016; Roozbeh et al., 2017b). Hence, our study aimed to estimate the prevalence of FVL mutation in women with pregnancy outcomes such as preterm birth, recurrent pregnancy loss (RPL), and other pregnancy complications. This will lead to a better understanding of the pathogenesis of those conditions.

\section{Methods}

In order to review the relevant literature, a comprehensive search was performed on several international databases, including Pubmed, EMBASE, ISI Web of Science, Scopus, ScienceDirect, Proquest and Google Scholar, along with Iranian databases. Boolean operators (OR, AND) were applied to produce combinations of appropriate keywords "factor V Leiden" OR "FVL mutation" AND "pregnancy outcomes", "preterm labor", "abortion", or "IVF". Using advanced search 
options of each search engine, articles were retrieved if they were published during 1996-2017 and had one of the first four keywords in either their title or abstract. The search was performed until August 2017. The inclusion criterion was any observational study that demonstrated adverse pregnancy outcomes in pregnant women with FVL mutations. We also inspected the reference list of the retrieved papers and searched other search engines. Papers in all languages were surveyed. Letters to the editor, case reports, case series articles, and studies without quantitative outcome data were excluded. The standard reporting of papers was demonstrated by using the 'Strengthening the Reporting of Observational Studies in Epidemiology' (STROBE) checklist (Roozbeh et al., 2017a). Data extraction was performed by authors individually; the data form included year of study, type of study, study method, participant, sample size, study result and outcomes. Newcastle-Ottawa Scale (NOS) was used for quality assessment of articles; tis tool was used in observational studies with the range of scale between 0-9 for the checklist (Roozbeh et al., 2016) (Fig. 1).

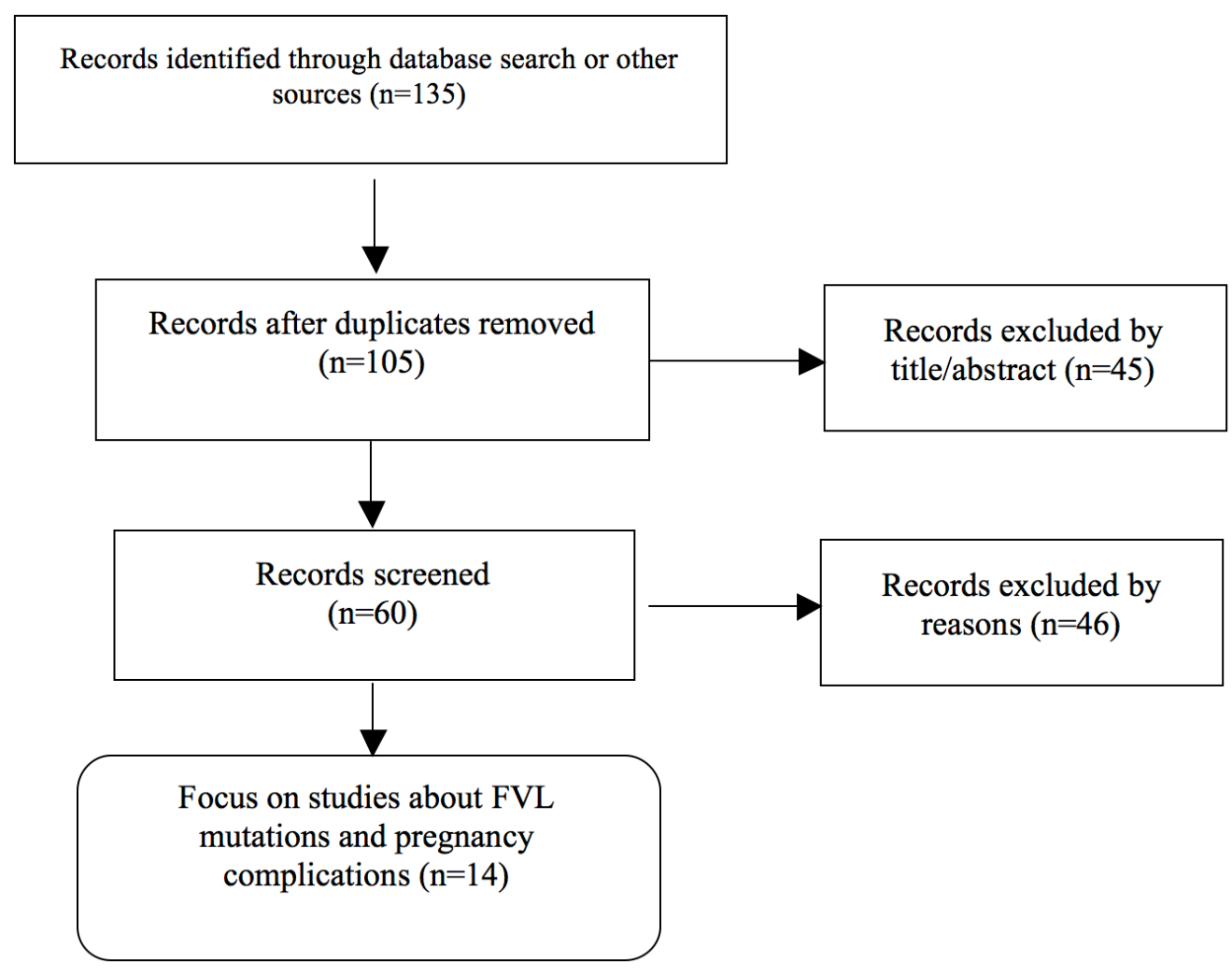

Figure 1. Flow chart for selection of articles for the review study. 


\section{Results}

A total of 14 studies were eligible based on the inclusion criteria. Table 1 presents a brief description of the selected studies and their findings. Most studies $(n=9)$ used a case-control design. One study had a nested case-control design. Two cohort studies and two cross-sectional studies were also included. After that, the key findings of the selected documents were summarized; the papers were scored by STROBE checklist (Table 1). The range of the STROBE score was between 5 and 20 . The sample size of the selected studies ranged from 10-4167 individuals. A total of 356,129 women were examined in the 14 reviewed studies. Most of studies evaluated the relationship between fetal loss and FVL $(n=8)$; only one study evaluated spontaneous abortion and IUGR. Three studies looked at IVF failure and FVL, and one study assessed other pregnancy complications. Among those 8 studies, only 3 of them (37.5\%) confirmed the relationship between fetal loss and FVL. The effect of FVL on spontaneous abortion and IVF failure was demonstrated in all the studies. Moreover, in the studies reviewed, there was no relationship shown between FVL and IUGR, preeclampsia, abruption, or small for gestational age (SGA).

Table 1. Reviewed articles about effects of FVL mutation on pregnancy outcomes

\begin{tabular}{|c|c|c|c|c|c|c|c|}
\hline $\begin{array}{l}\text { Author } \\
\text { (year) }\end{array}$ & $\begin{array}{l}\text { Study } \\
\text { type }\end{array}$ & Sample size & $\begin{array}{l}\text { Pregnancy } \\
\text { outcomes }\end{array}$ & Participant & Statistical analysis & Results & $\begin{array}{l}\text { STROBE } \\
\text { score }\end{array}$ \\
\hline $\begin{array}{l}\text { Foka (2000), } \\
\text { (Foka et al., } \\
2000)\end{array}$ & $\begin{array}{l}\text { case- } \\
\text { control }\end{array}$ & $\begin{array}{l}80 \text { cases, } \\
100 \text { controls }\end{array}$ & fetal loss & $\begin{array}{l}\text { Women with } \\
\text { RPL }\end{array}$ & $\begin{array}{l}\text { The odds ratio (OR) and } \\
95 \% \text { confidence interval (Cl) } \\
\text { for each was calculated. } \\
\text { Note: OR was used as a } \\
\text { measure of the strength of } \\
\text { the association. All p-values } \\
\text { were two tailed; p-value < } \\
0.05 \text { was considered as } \\
\text { statistically significant. }\end{array}$ & $\begin{array}{l}\text { The report } \\
\text { documented a } \\
\text { clear } \\
\text { association } \\
\text { between FVL } \\
\text { mutation and } \\
\text { fetal loss } \\
(\mathrm{OR}=5.5) \text {. }\end{array}$ & 18 \\
\hline $\begin{array}{l}\text { Lissaldelavig } \\
\text { ne (2005), } \\
\text { (Lissalde- } \\
\text { Lavigne et } \\
\text { al., 2005) }\end{array}$ & $\begin{array}{l}\text { nested } \\
\text { case- } \\
\text { control }\end{array}$ & $\begin{array}{l}3496 \text { pairs of } \\
\text { Caucasian } \\
\text { women }\end{array}$ & $\begin{array}{l}\text { spontaneous } \\
\text { abortion }\end{array}$ & $\begin{array}{l}\text { Women with } \\
\text { spontaneous } \\
\text { abortion }\end{array}$ & $\begin{array}{l}\text { Conditional logistic } \\
\text { regression and OR were } \\
\text { used }\end{array}$ & $\begin{array}{l}\text { There was an } \\
\text { association } \\
\text { between } \\
\text { FVL and } \\
\text { unexplained } \\
\text { pregnancy loss } \\
\text { during the first } \\
\text { intended } \\
\text { pregnancy } \\
\text { (p<0.001). }\end{array}$ & 20 \\
\hline
\end{tabular}




\begin{tabular}{|c|c|c|c|c|c|c|c|}
\hline $\begin{array}{l}\text { Ardestani } \\
\text { (2013), } \\
\text { (Ardestani et } \\
\text { al., 2013) }\end{array}$ & $\begin{array}{l}\text { case- } \\
\text { control }\end{array}$ & $\begin{array}{l}80 \text { cases, } \\
80 \text { controls }\end{array}$ & RPL & $\begin{array}{l}\text { Women with } \\
\text { RPL }\end{array}$ & $\begin{array}{l}\text { Results were compared by } \\
\text { chi-square (x2) test; } p \text {-value } \\
<0.05 \text { was set as } \\
\text { statistically significant. ORs } \\
\text { and } 95 \% \text { Cls were } \\
\text { calculated. }\end{array}$ & $\begin{array}{l}\text { The results } \\
\text { showed FVL } \\
\text { mutations were } \\
\text { not frequently } \\
\text { found in } \\
\text { women with } \\
\text { RPL. }\end{array}$ & 16 \\
\hline $\begin{array}{l}\text { Mierla } \\
\text { (2012), } \\
\text { (Mierla et al., } \\
\text { 2012) }\end{array}$ & $\begin{array}{l}\text { case- } \\
\text { control }\end{array}$ & $\begin{array}{l}283 \text { cases, } \\
100 \text { controls }\end{array}$ & fetal loss & $\begin{array}{l}\text { Women with } \\
\text { RPL }\end{array}$ & $\begin{array}{l}\text { The results of the two } \\
\text { groups were compared } \\
\text { using two-tailed Fisher's } \\
\text { exact test; data were } \\
\text { calculated using GraphPad } \\
\text { software. }\end{array}$ & $\begin{array}{l}\text { The study did } \\
\text { not find a } \\
\text { strong } \\
\text { association } \\
\text { between FVL } \\
\text { gene } \\
\text { polymorphism } \\
\text { and recurrent } \\
\text { miscarriages. }\end{array}$ & 15 \\
\hline $\begin{array}{l}\text { Cardona } \\
\text { (2012), } \\
\text { (Cardona et } \\
\text { al., 2012) }\end{array}$ & $\begin{array}{l}\text { case- } \\
\text { control }\end{array}$ & $\begin{array}{l}93 \text { cases, } \\
206 \text { controls }\end{array}$ & RPL & $\begin{array}{l}\text { Women with } \\
\text { RPL }\end{array}$ & $\begin{array}{l}\text { The allele and genotype } \\
\text { frequencies were compared } \\
\text { between patients and } \\
\text { controls using Mantel- } \\
\text { Haenszel chi-square test } \\
\text { and one-tail analysis. ORs } \\
\text { were calculated along with } \\
\text { Cornfield's 95\% Cl using Epi } \\
6 \text { Stat Calc. }\end{array}$ & $\begin{array}{l}\text { FVL was not } \\
\text { associated with } \\
\text { RPL. }\end{array}$ & 17 \\
\hline $\begin{array}{l}\text { Kazerooni } \\
\text { (2013), } \\
\text { (Kazerooni et } \\
\text { al., 2013) }\end{array}$ & $\begin{array}{l}\text { case- } \\
\text { control }\end{array}$ & $\begin{array}{l}-60 \text { cases with } \\
\text { RPL } \\
-60 \text { cases with } \\
\text { PCOS and } \\
\text { without RPL } \\
-60 \text { cases with } \\
\text { RPL and without } \\
\text { PCOS } \\
-60 \text { controls }\end{array}$ & $\begin{array}{l}\text { Combination } \\
\text { of RPL and } \\
\text { polycystic } \\
\text { ovary } \\
\text { syndrome } \\
\text { (PCOS) }\end{array}$ & $\begin{array}{l}\text { Women with } \\
\text { RPL and } \\
\text { PCOS }\end{array}$ & $\begin{array}{l}\text { Differences among groups } \\
\text { were compared using one- } \\
\text { way analysis of variance } \\
\text { (ANOVA). A two-sided p- } \\
\text { value }<0.05 \text { was considered } \\
\text { statistically significant. }\end{array}$ & $\begin{array}{l}\text { FVL was } \\
\text { associated with } \\
\text { PCOS and RPL. }\end{array}$ & 20 \\
\hline $\begin{array}{l}\text { Ivanov } \\
\text { (2009), } \\
\text { (Ivanov et al., } \\
\text { 2009) }\end{array}$ & $\begin{array}{l}\text { case- } \\
\text { control }\end{array}$ & $\begin{array}{l}-94 \text { women with } \\
\text { embryonic loss } \\
\text { before } 10 \text { wk } \\
-59 \text { women with } \\
\text { postembryonic } \\
\text { loss occurring } \\
\text { between 10-14 } \\
\text { wk } \\
\text {-100 healthy } \\
\text { women with at } \\
\text { least one } \\
\text { uncomplicated } \\
\text { full-term } \\
\text { pregnancy }\end{array}$ & RPL & $\begin{array}{l}\text { Women with } \\
\text { RPL }\end{array}$ & $\begin{array}{l}\text { Statistical analysis was } \\
\text { performed using } \\
\text { Statgraphics statistics } \\
\text { program (version 2.1). } \\
\text { Statistical significance and } \\
\text { differences in } \\
\text { genotype distribution were } \\
\text { calculated using chi-square } \\
\text { test. ORs and 95\% Cls were } \\
\text { calculated. }\end{array}$ & $\begin{array}{l}\text { FVL was not } \\
\text { associated with } \\
\text { RPL. }\end{array}$ & 16 \\
\hline
\end{tabular}




\begin{tabular}{|c|c|c|c|c|c|c|c|}
\hline $\begin{array}{l}\text { Serrano } \\
\text { (2011), } \\
\text { (Serrano et } \\
\text { al., 2011) }\end{array}$ & $\begin{array}{l}\text { case- } \\
\text { control }\end{array}$ & $\begin{array}{l}100 \text { cases, } \\
100 \text { controls }\end{array}$ & RPL & $\begin{array}{l}\text { Women with } \\
\text { RPL }\end{array}$ & $\begin{array}{l}\text { Data were expressed in the } \\
\text { form of mean } \pm S D \text { and } \% \text { (as } \\
\text { appropriate). To compare } \\
\text { the groups in terms of } \\
\text { categorical variables, chi- } \\
\text { square test (v2) was used. } \\
\text { The magnitude of } \\
\text { association via ORs and } \\
\text { their } 95 \% \text { Cls were } \\
\text { calculated by logistic } \\
\text { regression. }\end{array}$ & $\begin{array}{l}\text { No difference } \\
\text { was found in } \\
\text { the prevalence } \\
\text { of } \\
\text { these two } \\
\text { polymorphisms } \\
\text { in women with } \\
\text { RM or in a } \\
\text { control group } \\
\text { of healthy, } \\
\text { parous women. }\end{array}$ & 18 \\
\hline $\begin{array}{l}\text { Proite } \\
\text { (2016), } \\
\text { (Proite et al., } \\
\text { 2016) }\end{array}$ & $\begin{array}{l}\text { cross- } \\
\text { sectiona } \\
\mid\end{array}$ & $\begin{array}{l}247 \text { cases, } \\
247 \text { controls }\end{array}$ & RPL & $\begin{array}{l}\text { Women with } \\
\text { a history of } \\
\text { miscarriages }\end{array}$ & $\begin{array}{l}\text { The Hardy-Weinberg and } \\
\text { allelic/genotypic } \\
\text { frequencies were compared } \\
\text { using either chi-square test } \\
\text { or Fisher's exact test. The } \\
\text { ORs were derived from } \\
\text { logistic regression models. } \\
\text { For analysis of quantitative } \\
\text { variables, ANOVA was used } \\
\text { for normal data distribution } \\
\text { but Mann-Whitney test was } \\
\text { used when the assumption } \\
\text { of normal distribution of } \\
\text { data was rejected. }\end{array}$ & $\begin{array}{l}\text { FVL showed } \\
\text { probable } \\
\text { importance in } \\
\text { the genesis of } \\
\text { abortions due } \\
\text { to its } \\
\text { association with } \\
\text { greater } \\
\text { frequency of } \\
\text { normal } \\
\text { karyotype } \\
\text { miscarriages. }\end{array}$ & 17 \\
\hline $\begin{array}{l}\text { ALHusseini } \\
\text { (2011) (Al } \\
\text { Husseini et } \\
\text { al., 2011) }\end{array}$ & $\begin{array}{l}\text { cross- } \\
\text { sectiona } \\
\mid\end{array}$ & $\begin{array}{l}20 \text { cases, } \\
40 \text { controls }\end{array}$ & IVF & $\begin{array}{l}\text { Women with } \\
\text { IVF }\end{array}$ & $\begin{array}{l}\text { The results were presented } \\
\text { as mean+SD; comparisons } \\
\text { of categorical variables were } \\
\text { made between case and } \\
\text { control groups using chi } \\
\text { square test, student " } t \text { " test, } \\
\text { and F test. The Spearman's } \\
\text { rank correlation coefficient } \\
\text { was used to measure the } \\
\text { closeness of a linear } \\
\text { relationship between the } \\
\text { results of mutation in } \\
\text { thrombophilic genes and } \\
\text { the frequency of } \\
\text { repeated IVF-embryo } \\
\text { transfer cycle. }\end{array}$ & $\begin{array}{l}\text { There were } \\
\text { significant } \\
\text { increases of } \\
\text { allelic frequency } \\
\text { of FVL in } \\
\text { women with } \\
\text { repeated IVF- } \\
\text { embryo transfer } \\
\text { failure. }\end{array}$ & 16 \\
\hline
\end{tabular}




\begin{tabular}{|c|c|c|c|c|c|c|c|}
\hline $\begin{array}{l}\text { Safdarian } \\
\text { (2014), } \\
\text { (Safdarian et } \\
\text { al., 2014) }\end{array}$ & $\begin{array}{l}\text { case- } \\
\text { control }\end{array}$ & $\begin{array}{l}96 \text { cases, } \\
95 \text { controls }\end{array}$ & IVF failure & $\begin{array}{l}\text { Women, with } \\
\text { a history of } \\
\text { recurrent IVF } \\
\text { failure }\end{array}$ & $\begin{array}{l}\text { Numerical variables were } \\
\text { reported as mean } \pm \text { SD. } \\
\text { Independent sample t-tests } \\
\text { and chi-square tests were } \\
\text { used to compare } \\
\text { quantitative and qualitative } \\
\text { variables, } \\
\text { respectively, and logistic } \\
\text { regression analysis was also } \\
\text { used. } \\
\text { Univariable analysis was } \\
\text { performed, in which } \\
\text { ORs and } 95 \% \text { Cls were } \\
\text { calculated. P-value } \\
\leq 0.05 \text { was considered to be } \\
\text { statistically } \\
\text { significant. }\end{array}$ & $\begin{array}{l}\text { Thrombophilia, } \\
\text { mutation of } \\
\text { FVL, and/or } \\
\text { homozygote } \\
\text { form of } \\
\text { methylenetetra } \\
\text { hydrofolate } \\
\text { reductase } \\
\text { (MTHFR) } \\
\text { mutation were } \\
\text { risk factors for } \\
\text { recurrent IVF } \\
\text { failure. }\end{array}$ & 17 \\
\hline $\begin{array}{l}\text { Ricci (2011), } \\
\text { (Ricci et al., } \\
\text { 2011) }\end{array}$ & cohort & $\begin{array}{l}510 \text { cases, } \\
490 \text { controls }\end{array}$ & IVF failure & $\begin{array}{l}\text { Women } \\
\text { requiring IVF }\end{array}$ & $\begin{array}{l}\text { Mann-Whitney U-test was } \\
\text { used for continuous } \\
\text { variables, and Fisher's exact } \\
\text { test or chi-square test (as } \\
\text { appropriate) was used for } \\
\text { categorical variables, along } \\
\text { with Bonferroni correction } \\
\text { for multiple tests and } \\
\text { multiple logistic regression } \\
\text { analysis. P-value < } 0.05 \text { was } \\
\text { considered as significant. }\end{array}$ & $\begin{array}{l}\text { FVL in } \\
\text { asymptomatic } \\
\text { women and in } \\
\text { the absence of } \\
\text { other risk } \\
\text { factors did not } \\
\text { influence IVF } \\
\text { outcome. }\end{array}$ & 18 \\
\hline $\begin{array}{l}\text { Silver } \\
\text { (2010), } \\
\text { (Silver et al., } \\
\text { 2010) }\end{array}$ & cohort & 4157 cases & $\begin{array}{l}\text { Pregnancy } \\
\text { loss, } \\
\text { preeclampsi } \\
\text { a, abruption, } \\
\text { and SGA }\end{array}$ & $\begin{array}{l}\text { Uncomplicate } \\
\text { d singleton } \\
\text { pregnancies } \\
\text { at } 14 \text { weeks } \\
\text { of } \\
\text { gestation or } \\
\text { less }\end{array}$ & $\begin{array}{l}\text { Multivariable } \\
\text { logistic regression analysis } \\
\text { was performed, controlling } \\
\text { for age, race, prior } \\
\text { pregnancy loss, prior } \\
\text { SGA neonates, and family } \\
\text { history of } \\
\text { thromboembolism. } \\
\text { Proportions were compared } \\
\text { using the } \\
\text { Fisher exact or } \text { X2 test; } \\
\text { continuous variables were } \\
\text { compared using the } \\
\text { Wilcoxon rank-sum test. } \\
\text { Exact binomial confidence } \\
\text { limits were calculated when } \\
\text { indicated } \\
\text { owing to small sample size. }\end{array}$ & $\begin{array}{l}\text { FVL was not } \\
\text { associated with } \\
\text { pregnancy } \\
\text { outcome. }\end{array}$ & 16 \\
\hline $\begin{array}{l}\text { Infante- } \\
\text { Rivard } \\
\text { (2002), } \\
\text { (Infante- } \\
\text { Rivard et al., } \\
\text { 2002) }\end{array}$ & $\begin{array}{l}\text { case- } \\
\text { control }\end{array}$ & $\begin{array}{l}493 \text { cases, } \\
472 \text { controls }\end{array}$ & IUGR & $\begin{array}{l}\text { Newborns } \\
\text { with IUGR }\end{array}$ & $\begin{array}{l}\text { The OR for one copy of the } \\
\text { variant was calculated with } \\
\text { the use of single-integer } \\
\text { variables. }\end{array}$ & $\begin{array}{l}\text { FVL was not } \\
\text { associated with } \\
\text { IUGR. }\end{array}$ & 20 \\
\hline
\end{tabular}




\section{Discussion}

Considering the importance of pregnancy outcomes, we reviewed studies which focused on the potential role of FVL mutation on adverse pregnancy outcomes. The reviewed studies suggested unclear associations between FVL mutation and PRL, stillbirth, IUGR, preeclampsia, or placental abruption. Our results indicated that the exact effects of hereditary thrombophilia on RPL is still a controversial issue. A Greek study found FVL in about $25 \%$ of women with a history of fetal loss and concluded that this mutation could be a risk factor for RPL (Foka et al., 2000). Another study on Caucasian women indicated FVL had a significant relationship with the risk of spontaneous abortion occurring from the 10th week of the first intended pregnancy (Lissalde-Lavigne et al., 2005).

In contrast, some researchers do not accept FVL as a risk factor for RPL. For instance, according to an Iranian study, FVL were not frequently found in women with RPL (Ardestani et al., 2013). Another study found no significant differences in the allele frequencies and genotype distribution for FVL gene polymorphisms for patients with RPL versus control subjects (Mierla et al., 2012). Goodman et al. reported significantly higher frequency of FVL mutation among American women with a history of RPL (Goodman et al., 2006). In contrast, another study on a similar population of American women did not detect any differences in the frequency of definite FVL mutations (Colman, 2006). Previous meta-analyses introduced FVL as the only thrombophilic mutation involved in RPL (Rey et al., 2003; Robertson et al., 2006).

The frequency of thrombophilic mutations varies in different ethnic groups and societies. FVL was rarely detected in Malay women with RPL (Ayadurai et al., 2009). Brazilian FVL carriers had a 4.9 fold higher risk of RPL than the non-carrier counterparts. Likewise, the risk of RPL was five times higher in Uruguayan women heterozygous for FVL than in non-carriers (Daniela et al., 2004). Two prospective cohort studies have also reported the absence of any associations between hereditary thrombophilia and RPL (Cardona et al., 2012). Kazerooni et al. detected elevated levels of thrombophilic parameters in patients with a combination of polycystic ovary syndrome (PCOS) and RPL. They also found FVL mutations to be more frequent in these individuals than in PCOS patients without RPL (Kazerooni et al., 2013). A study in Portugal negated any relationship between FVL and RPL during the first 10 weeks of gestation. It concluded that testing for these mutations in the initial screening of women with RPL and negative personal thromboembolic history was not cost-effective (Serrano et al., 2011). Similarly, in a controlled study, Dilley et al. found the frequency of FVL to be similar in 60 women with RPL and 92 controls without a history of miscarriage (Dilley et al., 2002).

Meanwhile, previous meta-analyses have suggested FVL-related losses to be more common after the 14th week than in the first trimester (Kist et al., 2008; Robertson et al., 2006). In a study of Caucasian women with unexplained RPL, Ivanov et al. found FVL to have a similar prevalence in subjects with embryonic 
losses and controls. In contrast, FVL was more prevalent (18.6\%) in women who experienced pregnancy losses during the 10-14th week of gestation (Ivanov et al., 2009). Considering the controversial results of previous studies, clinicians prefer to incorporate FVL testing in RPL investigation protocols (Kist et al., 2008; Norrie et al., 2009). Due to lack of adequate evidence, recent guidelines on the assessment and management of women with RPL, published by the Royal College of Obstetricians and Gynecologist and the American College of Obstetricians and Gynecologists, do not assert the need for routine thrombophilia screening and anticoagulant therapy (Idali et al., 2012).

The result of this review showed that heterozygosity for FVL mutation increases the risk of venous thromboembolism during pregnancy, implantation failure, and fetal loss after IVF. Significantly higher rates of pregnancy loss have been found in heterozygous and/or homozygous carriers of FVL gene mutations compared to their control counterparts. Al Husseini et al. confirmed an association between the presence of FVL and higher rates of fetal loss following IVF (Al Husseini et al., 2011). Similarly Azem et al. suggested higher frequency of thrombophilia in subjects with recurrent IVF-embryo transfer failure than in those without such an experience (Azem et al., 2004). Qublan et al. reported FVL to be more common in women with recurrent IVF failure than in subjects with successful IVF experience and healthy women (Qublan et al., 2006). Moreover, microthrombosis at the implantation site may alter the invasion of syncytiotrophoblast to the mother's vessels and lead to implantation failure or fetal loss. In fact, the existence of at least one thrombophilic factor has been proven in female patients with recurrent IVF-embryo transfer failures (Azem et al., 2004). On the other hand, following the detection of greater ICSI success in FVL carriers, Göpel et al. concluded that the thrombotic tendency in mothers with FVL mutation promoted successful fetal implantation (Göpel et al., 2001). Colman et al. compared healthy fertile women with those experiencing recurrent implantation failure and highlighted the presence of at least three gene mutations in the latter group (Colman, 2006).

In one study, Qublan et al. compared 90 women with more than two consecutive failed IVF attempts (group A) and two control groups (groups B and C). The control group was comprised of 90 women whose first IVF embryo transfer led to successful pregnancy. The control group C consisted of 100 women with spontaneous conception, at least one unsuccessful pregnancy, and no history of miscarriage. The researchers found higher frequency of FVL in group A (14.4\%) than in groups B (1\%) and C (2\%) (Qublan et al., 2006). While Grandone et al. published similar findings (Grandone et al., 2001), other researchers have generally failed to establish such a link (Azem et al., 2004). Some studies indicated that after having at least one thrombophilia, the mutation of factor $\mathrm{V}$ Leiden is a risk factor for recurrent IVF failure (Ricci et al., 2011; Safdarian et al., 2014). Moreover, according to our results, there is little evidence to suggest a relationship between IUGR and thrombophilia. A study in Germany revealed that inherited risk factors, particularly that FVL, boosted the risk of Low Birth Weight (LBW) (von Kries et al., 2001). In a very large study, Infante-Rivard et al. refuted 
the idea that inherited thrombophilia served as a clinically significant cause of IUGR (Infante-Rivard et al., 2002).

\title{
Conclusion
}

In summary, the exact effects of hereditary thrombophilia on pregnancy outcomes are still unclear and controversial. Therefore, screening patients for thrombophilic polymorphisms might be helpful in identifying patients at increased risk for thrombophilic events and other related adverse pregnancy outcomes. Furthermore, such screening would determine the target group for prophylactic therapy. Nevertheless, based on Royal College of Obstetricians and Gynecologists, there is still a lack of evidence in favor of routine thrombophilia screening and anticoagulant-based interventions during pregnancy. Therefore, we recommend that the screening for thrombophilia should be encouraged. Regardless of the limitations of the current study, we believe that the results emphasize the relevance of the topic of thrombophilia in pregnancy complications and point the need for further research. Since the outbreak of all types of thrombophilic state including inherited and acquired in women with pregnancy complications, is not so infrequent, every specialist should consider these conditions and investigate them in their patients with severe pregnancy complications.

\section{Abbreviations}

\author{
aCL: anticardiolipin antibodies \\ APCR: activated protein $C$ resistance \\ APS: Antiphospholipid Syndrome \\ AT III: antithrombin \\ $a_{\beta} 2$-GPI: anti- ${ }_{\beta}$-2-glycoprotein I \\ FVL: Factor $V$ Leiden \\ HRT: Hormone replacement therapy \\ IUGR: Intrauterine Growth Restriction \\ IVF: In Vitro Fertilization \\ LA: lupus anticoagulant \\ LBW: Low Birth Weight \\ MTHFR: Methylenetetra hydrofolate reductase \\ NOS: Newcastle-Ottawa Scale \\ PCOS: polycystic ovary syndrome \\ PT: prothrombin time \\ RPL: recurrent pregnancy loss
}




\section{Acknowledgements}

The authors wish to express their gratitude to the Shahid Beheshti University of Medical Sciences (Tehran, Iran) and Hormozgan University of Medical Sciences (BandarAbbas, Iran).

\section{Author Contribution}

FA and NR developed main idea and were responsible of the article writing. FB was responsible for assessment of eligibility criteria of papers. All authors read and approved the final manuscript.

\section{References}

Abdi, F., \& Roozbeh, N. (2016). The effects of Humulus Lupulus L.) Hops) on Menopausal Vasomotor Symptoms: A Systematic Review and Meta-analysis. Majallah-i Zanan, Mamai va Nazai-i Iran, 19, 9-17.

Al Husseini, N. F., Rezk, A. Y., Odah, M. M., El Rahman, S. M., \& Ali, A. I. (2011). Thrombophilic Genes Mutations in Women with Repeated In-Vitro Fertilization Failure. American Medical Journal, 2(1), 7-12. https://doi.org/10.3844/amjsp.2011.7.12

Ardestani, M. T., Nodushan, H. H., Aflatoonian, A., Ghasemi, N., \& Sheikhha, M. H. (2013). Case control study of the factor $V$ Leiden and factor II G20210A mutation frequency in women with recurrent pregnancy loss. Iranian Journal of Reproductive Medicine, 11, 61 .

Ayadurai, T., Muniandy, S., \& Omar, S. Z. (2009). Thrombophilia investigation in Malaysian women with recurrent pregnancy loss. Journal of Obstetrics and Gynaecology Research, 35(6), 1061-1068. https://doi.org/10.1111/j. 1447-0756.2009.01067.x

Azem, F., Many, A., Yovel, I., Amit, A., Lessing, J. B., \& Kupferminc, M. J. (2004). Increased rates of thrombophilia in women with repeated IVF failures. Human Reproduction (Oxford, England), 19(2), 368-370. https://doi.org/10.1093/humrep/ deh069

Cardona, H., Castañeda, S. A., Cardona Maya, W., Alvarez, L., Gómez, J., Gómez, J., . . . Cadavid, Á. P. (2012). Lack of association between recurrent pregnancy loss and inherited thrombophilia in a group of Colombian patients. Thrombosis, $\bullet \bullet \bullet, 2012$.

Carrington, B., Sacks, G., \& Regan, L. (2005). Recurrent miscarriage: Pathophysiology and outcome. Current Opinion in Obstetrics \& Gynecology, 17(6), 591-597. https:// doi.org/10.1097/01.gco.0000194112.86051.26 
Colman, R. W. (2006). Are hemostasis and thrombosis two sides of the same coin? The Journal of Experimental Medicine, 203(3), 493-495. https://doi.org/10.1084/jem. 20060217

Daniela, L., De Lisa, E., Dellepiane, M., Storch, E., Attarian, D., Ferrari, A., . . Motta, N. (2004). Trombofilia y pérdida recurrente de embarazo. La Revista Medica del Uruguay, 20, 106-113.

De Stefano, V., \& Leone, G. (1995). Resistance to activated protein C due to mutated factor $V$ as a novel cause of inherited thrombophilia. Haematologica, 80, 344-356.

Dilley, A., Benito, C., Hooper, W., Austin, H., Miller, C., El-Jamil, M., . . Patterson-Barnett, A. (2002). Mutations in the factor $V$, prothrombin and MTHFR genes are not risk factors for recurrent fetal loss. The Journal of Maternal-Fetal \& Neonatal Medicine, 11(3), 176182. https://doi.org/10.1080/jmf.11.3.176.182

Dizon-Townson, D., Miller, C., Sibai, B., Spong, C. Y., Thom, E., Wendel, G., Jr., . . . Moawad, A. (2005). The relationship of the factor $V$ Leiden mutation and pregnancy outcomes for mother and fetus. Obstetrics and Gynecology, 106(3), 517-524. https:// doi.org/10.1097/01.AOG.0000173986.32528.ca

Doyle, N. M., \& Monga, M. (2004). Thromboembolic disease in pregnancy. Obstetrics and Gynecology Clinics of North America, 31(2), 319-344. https://doi.org/10.1016/ j.ogc.2004.03.008

Foka, Z., Lambropoulos, A., Saravelos, H., Karas, G., Karavida, A., Agorastos, T., . . . Kotsis, A. (2000). Factor $V$ Leiden and prothrombin G20210A mutations, but not methylenetetrahydrofolate reductase C677T, are associated with recurrent miscarriages. Human Reproduction (Oxford, England), 15(2), 458-462. https://doi.org/ 10.1093/humrep/15.2.458

Gawish, G. E. (2011). Molecular characterization of factor $V$ leiden G1691A and prothrombin G20210A mutations in Saudi newborns with stroke. Biochemical Genetics, 49(9-10), 601-610. https://doi.org/10.1007/s10528-011-9435-7

Goodman, C. S., Coulam, C. B., Jeyendran, R. S., Acosta, V. A., \& Roussev, R. (2006). Which thrombophilic gene mutations are risk factors for recurrent pregnancy loss? American Journal of Reproductive Immunology, 56(4), 230-236. https://doi.org/ 10.1111/j.1600-0897.2006.00419.x

Göpel, W., Ludwig, M., Junge, A. K., Kohlmann, T., Diedrich, K., \& Möller, J. (2001). Selection pressure for the factor-V-Leiden mutation and embryo implantation. Lancet, 358(9289), 1238-1239. https://doi.org/10.1016/S0140-6736(01)06354-1

Grandone, E., Colaizzo, D., Bue, A. L., Checola, M. G., Cittadini, E., \& Margaglione, M. (2001). Inherited thrombophilia and in vitro fertilization implantation failure. Fertility and Sterility, 76(1), 201-202. https://doi.org/10.1016/S0015-0282(01)01832-5

Idali, F., Zareii, S., Mohammad-Zadeh, A., Reihany-Sabet, F., Akbarzadeh-Pasha, Z., Khorram-Khorshid, H. R., .. . Jeddi-Tehrani, M. (2012). Plasminogen activator inhibitor 1 and methylenetetrahydrofolate reductase gene mutations in Iranian women with polycystic ovary syndrome. American Journal of Reproductive Immunology, 68(5), 400407. https://doi.org/10.1111/aji.12002

Infante-Rivard, C., Rivard, G.-E., Yotov, W. V., Génin, E., Guiguet, M., Weinberg, C., . . . Feoli-Fonseca, J. C. (2002). Absence of association of thrombophilia polymorphisms with intrauterine growth restriction. The New England Journal of Medicine, 347(1), 1925. https://doi.org/10.1056/NEJM200207043470105 
Ivanov, P. D., Komsa-Penkova, R. S., Konova, E. I., Kovacheva, K. S., Simeonova, M. N., \& Popov, J. D. (2009). Association of inherited thrombophilia with embryonic and postembryonic recurrent pregnancy loss. Blood Coagulation \& Fibrinolysis, 20(2), 134140. https://doi.org/10.1097/MBC.0b013e32832545f3

Kazerooni, T., Ghaffarpasand, F., Asadi, N., Dehkhoda, Z., Dehghankhalili, M., \& Kazerooni, Y. (2013). Correlation between thrombophilia and recurrent pregnancy loss in patients with polycystic ovary syndrome: A comparative study. Journal of the Chinese Medical Association, 76(5), 282-288. https://doi.org/10.1016/j.jcma.2013.01.009

Kist, W. J., Janssen, N. G., Kalk, J. J., Hague, W. M., Dekker, G. A., \& Vries, J. d. (2008). Thrombophilias and adverse pregnancy outcome-A confounded problem! Thrombosis and Haemostasis, 99, 77.

Kupferminc, M. J., Eldor, A., Steinman, N., Many, A., Bar-Am, A., Jaffa, A., . . Lessing, J. B. (1999). Increased frequency of genetic thrombophilia in women with complications of pregnancy. The New England Journal of Medicine, 340(1), 9-13. https://doi.org/ 10.1056/NEJM199901073400102

Kupferminc, M. J., Rimon, E., Many, A., Sharon, M., Lessing, J. B., \& Gamzu, R. (2011). Low molecular weight heparin treatment during subsequent pregnancies of women with inherited thrombophilia and previous severe pregnancy complications. The Journal of Maternal-Fetal \& Neonatal Medicine, 24(8), 1042-1045. https://doi.org/ $\underline{10.3109 / 14767058.2010 .545911}$

Lissalde-Lavigne, G., Fabbro-Peray, P., Cochery-Nouvellon, E., Mercier, E., RipartNeveu, S., Balducchi, J.-P., . . . Gris, J.-C. (2005). IN FOCUS: Factor V Leiden and prothrombin G20210A polymorphisms as risk factors for miscarriage during a first intended pregnancy: the matched case-control 'NOHA first'study. Journal of Thrombosis and Haemostasis, 3(10), 2178-2184. https://doi.org/10.1111/j. 1538-7836.2005.01581.x

Mierla, D., Szmal, C., Neagos, D., Cretu, R., Stoian, V., \& Jardan, D. (2012). Association of Prothrombin (A20210G) and Factor V Leiden (A506G) with Recurrent Pregnancy Loss. Maedica, 7, 222.

Norrie, G., Farquharson, R. G., \& Greaves, M. (2009). Screening and treatment for heritable thrombophilia in pregnancy failure: Inconsistencies among UK early pregnancy units. British Journal of Haematology, 144(2), 241-244. https://doi.org/ 10.1111/j.1365-2141.2008.07444.x

Pavlova, E., Chemev, T., Chemev, A., and Karagiozova, Z. (2008). Pregnancy and issues with inherited and acquired thrombophilia. Journal of IMAB-Annula Proceeding, 21-22.

Proite, M. M., de Moraes Malinverni, A. C., Oshima, C. T. F., de Souza Ishigai, M. M., Moron, A. F., da Silva, I. D. C. G., \& da Silva, F. R. (2016). Mutations in the Gene for Factor $V$ Leiden and G20210A Prothrombin Polymorphism in Women With Recurrent Spontaneous Abortion: A Retrospective Study in a Brazilian Population. Journal of Clinical Gynecology and Obstetrics, 5(3), 85-91. https://doi.org/10.14740/jcgo412e

Qublan, H. S., Eid, S. S., Ababneh, H. A., Amarin, Z. O., Smadi, A. Z., Al-Khafaji, F. F., \& Khader, Y. S. (2006). Acquired and inherited thrombophilia: Implication in recurrent IVF and embryo transfer failure. Human Reproduction (Oxford, England), 21(10), 26942698. https://doi.org/10.1093/humrep/del203

Rai, R., \& Regan, L. (2006). Recurrent miscarriage. Lancet, 368(9535), 601-611. https:// doi.org/10.1016/S0140-6736(06)69204-0 
Rey, E., Kahn, S. R., David, M., \& Shrier, I. (2003). Thrombophilic disorders and fetal loss: A meta-analysis. Lancet, 361(9361), 901-908. https://doi.org/10.1016/ S0140-6736(03)12771-7

Ricci, G., Bogatti, P., Fischer-Tamaro, L., Giolo, E., Luppi, S., Montico, M., ... Morgutti, M. (2011). Factor $V$ Leiden and prothrombin gene G20210A mutation and in vitro fertilization: Prospective cohort study. Human Reproduction (Oxford, England), 26(11), 3068-3077. https://doi.org/10.1093/humrep/der261

Robertson, L., Wu, O., Langhorne, P., Twaddle, S., Clark, P., Lowe, G., ... Regan, L. (2006). Thrombophilia in pregnancy: A systematic review. British Journal of Haematology, 132(2), 171-196. https://doi.org/10.1111/j.1365-2141.2005.05847.x

Rodger, M. A. (2013). An update on thrombophilia and placenta mediated pregnancy complications: What should we tell our patients? Thrombosis Research, 131(Suppl 1), S25-S27. https://doi.org/10.1016/S0049-3848(13)70015-X

Roozbeh, N., Azizi, M., \& Darvish, L. (2017a). Pregnancy Outcome of Abnormal Nuchal Translucency: A Systematic Review. Journal of Clinical and Diagnostic Research : JCDR, 11, QC12.

Roozbeh, N., Darvish, L., \& Abdi, F. (2017b). Hypoglycemic effects of Acacia nilotica in type II diabetes: A research proposal. BMC Research Notes, 10(1), 331. https://doi.org/ 10.1186/s13104-017-2646-1

Roozbeh, N., Nahidi, F., \& Hajiyan, S. (2016). Barriers related to prenatal care utilization among women. Saudi Medical Journal, 37(12), 1319-1327. https://doi.org/10.15537/ smj.2016.12.15505

Safdarian, L., Najmi, Z., Aleyasin, A., Aghahosseini, M., Rashidi, M., \& Asadollah, S. (2014). Recurrent IVF failure and hereditary thrombophilia. Iranian Journal of Reproductive Medicine, 12, 467.

Serrano, F., Lima, M. L., Lopes, C., Almeida, J. P., \& Branco, J. (2011). Factor V Leiden and prothrombin G20210A in Portuguese women with recurrent miscarriage: Is it worthwhile to investigate? Archives of Gynecology and Obstetrics, 284(5), 1127-1132. https://doi.org/10.1007/s00404-010-1834-1

Silver, R. M., Zhao, Y., Spong, C. Y., Sibai, B., Wendel, G., Jr., Wenstrom, K., . . . Miodovnik, M. (2010). Prothrombin gene G20210A mutation and obstetric complications. Obstetrics and Gynecology, 115(1), 14-20. https://doi.org/10.1097/ AOG.0b013e3181c88918

Simcox, L. E., Ormesher, L., Tower, C., \& Greer, I. A. (2015). Thrombophilia and pregnancy complications. International Journal of Molecular Sciences, 16(12), 2841828428. https://doi.org/10.3390/ijms161226104

von Kries, R., Junker, R., Oberle, D., Kosch, A., \& Nowak-Gottl, U. (2001). Foetal growth restriction in children with prothrombotic risk factors. THROMBOSIS AND HAEMOSTASIS-STUTTGART, 86, 1012-1016. 